\title{
SOCIALINIO DARBUOTOJO PSICHOSOCIALINĖS PAGALBOS POREIKIS ŠEIMAI, PRARADUSIAI VAIKĄ DE்L ONKOLOGINĖS LIGOS
}

\author{
Virginija Kondratavičienė, Iveta Šikšniuvienė \\ Kauno kolegijos Medicinos fakultetas
}

Raktažodžiai: onkologinè liga, socialinis darbas, socialinis darbuotojas, šeima, poreikis, psichosocialinè pagalba.

\begin{abstract}
Santrauka
Lietuvoje stebimas didejjantis vaikų sergamumas onkologinèmis ligomis. Vaiko mirties patirtis ypač skaudi tèvams, kai jiems tenka išgyventi baimès, nerimo, liūdesio, nevilties ar pykčio emocijas, trukdančias toliau tęsti visaverti gyvenimą. Tẻvams, išgyvenantiems netektį, reikalinga pagalba, kuri atlieptų jų viltis ir poreikius, padètų ịveikti socialinès atskirties jausmą, parodytų, kad pagalba yra čia pat ir galima ją gauti. Tyrimas atskleidè, kad žinios apie ligą prièmimas ir prisitaikymas prie naujų aplinkybių priklauso nuo tèvų pirminio kontakto su gydančiuoju gydytoju. Gydytojo dèmesys, aiškus ligos apibūdinimas, gydymo aptarimas, nuolatinis abipusis komunikavimas švelnina prisitaikymo etapą. Tyrimas atskleidè ir laiku teikiamos kompleksinès (gydytojo, psichologo, socialinio darbuotojo) pagalbos poreiki, kuris svarbus visą gydymosi laikotarpi. Po vaiko netekties tèvams ypač ryškus socialinio darbuotojo pagalbos poreikis. Tyrimo metu išaiškejo tarpinstitucinio bendradarbiavimo būtinumas, siekiant padèti šeimai išgyventi netektị, suteikti būtiną psichosocialinę pagalbą, stebèti, analizuoti pokyčius visą gedẻjimo laikotarpi, o dažnai ir ilgiau.
\end{abstract}

\section{Ivadas}

Onkologinėmis ligomis kasmet suserga vis daugiau žmonių, tarp jų ir jaunesnių nei 18 metų. Lietuvoje stebimas šių susirgimų skaičiaus didèjimas tarp vaikų. Nacionalinis vèžio institutas [15] 2012 metais užregistravo 60 naujų vaikų susirgimų atvejų. 2016 metais Higienos institutas [13] pateikè skaičius, kurie parodè susirgimų skaičiaus didèjimo tendenciją. 2016 metais užregistruoti 149, o 2017 metais jau 163 nauji atvejai. Lietuvoje vaikų onkologija sutelkta dviejuose pagrindiniuose gydymo centruose - Vilniaus universiteto ligoninès Santaros klinikose (Vaikų onkohematologiniame skyriuje) ir Lietuvos sveikatos mokslų universiteto ligoninès Kauno klinikose (Vaikų ligų klinikos vaikų onkologijos skyriuje).

Gerèjant ligų diagnostikai ir stiprejjant profilaktikai [18], atsirandant naujų gydymo priemonių, aktyviai veikiant paramos ir labdaros organizacijoms, kartu sprendžiamos ịvairios gydymo, slaugos ir socialinès problemos. Šių veiksnių bei rūpestingų tèvų aktyvumo dèka, stebima mirtingumo nuo šios ligos mažejimo tendencija, tačiau žinia apie vaiko onkologinę ligą sukrečia šeimą, baugina ir keičia jos tolesnị gyvenimą. Ligai progresuojant, susitaikyti su artejjančia netektimi tampa vis sunkiau, demesys koncentruojamas tik $\mathfrak{i}$ vaiką ir jo būseną, pamirštant save ir aplinkinius.

Lietuvoje nèra išsamių tyrimų, kurie atskleistų tèvų, netekusių savo vaiko dèl onkologinès ligos, patirtị ir pagalbos poreikị. 2016 metais Vytauto Didžiojo universiteto Socialinio darbo katedros absolventė I. Baluckaite baigiamajame bakalauro darbe nagrinėjo šią temą ir tėvų, praradusių vaiką dèl onkologinès ligos, prisitaikymo prie netekties patirti. Tyrimo rezultatai parodè, kad tema aktuali, būtina tolimesnè problemos analizè ir efektyvių pagalbos būdų paieška.

Mirus vaikui, tèvai, o dažnai tik motina, patiria ịvairių psichosocialinių problemų. Kyla klausimas, ką daryti, kokia pagalba galima ir reikalinga, organizuojant vaiko laidotuves, kur kreiptis, kaip gyventi toliau?

Alkoholis, mintys apie savižudybę, bandymai pasitraukti iš gyvenimo, depresija, socialinė atskirtis, draugų, nežinančių kaip bendrauti su tokia šeima, nutolimas. Tai tik dalis neigiamų pasekmių, kurios gali būti sprendžiamos, aktyviai dalyvaujant socialiniam darbuotojui.

Vaiko mirties patirtis ypač skaudi tèvams. Apsiprasti su šia mintimi ir grịžti ị kasdienị gyvenimą nelengva. Siekiant padèti tẻvams išgyventi netektį, reikalinga pagalba, kuri atlieptų tèvų viltis ir poreikius, padètų jiems nesijausti socialiai atskirtiems, parodytų, kad pagalba yra čia pat ir galima ją 
gauti. Psichosocialinės pagalbos ir komandinio darbo aktualumą onkologinès ligos atveju pažymi dauguma autoriu $[3,14,17,22]$, kurie teigia, jog socialinis darbuotojas yra tarsi atspirties taškas, kai reikia susivokti ir prisitaikyti prie gyvenimo pokyčių.

Tyrimo tikslas - nustatyti socialinio darbuotojo psichosocialinès pagalbos poreikị šeimai, praradusiai vaiką dèl onkologinès ligos.

\section{Tyrimo medžiaga ir metodai}

Pasirinktas kokybinis fenomenologinis-etnografinis tyrimo metodas, norint surinkti reikalingos informacijos, nesudarant griežtai struktūruotos tyrimo aplinkos.

Kokybinių duomenų analizè buvo pagrista indukcine logika [6]. Tai reiškia, kad naujų žinių pagrindas yra empiriniai duomenys, o ne iš anksto suformuotos teorinès koncepcijos. Kokybinių duomenų analizei iš duomenų masyvo buvo atrinktos svarbiausios kategorijos, modeliai ar sąsajos, neturint išankstinès nuomonès. Šio tyrimo informantai - skirtingus netekties laikotarpius ir etapus išgyvenantys asmenys, turintieji ivvairios negatyvios ir pozityvios patirties. Juos jungianti bendra sąsaja - vaiko netektis.

Tyrimo etika ir konfidencialumas. Atliekant kokybinius tyrimus, pirmiausia stengiamasi pasirūpinti tyrimo dalyviu ir jo gerove $[19,23]$. Autorių teigimu, tyrimo dalyvis, jausdamasis nesaugus, gali neatsiverti tyrèjui. Autoriai apibūdina tyrimui tinkamą aplinką, kuri informantui nekeltų streso ar neigiamų emocijų, todèl kiekvienas susitikimas vyko informanto nurodytoje vietoje jo pasirinktu laiku. Tyrime dalyvavo 4 skirtinguose Lietuvos regionuose gyvenančios šeimos, praradusios vaikus dèl onkologinès ligos. Tai asmeninès pažintys. Pusiau struktūruotas interviu leido objektyviai vertinti gautą informaciją, išvengti išankstinių nuostatų, įsitikinimų ir kt. Vadovaujantis tyrimo dalyvių privatumo principu, visa informacija, kurią tyrejjas gauna iš respondentų, yra konfidenciali. Tyrime dalyvavusių informantų inicialai pakeisti. Nenurodyta nei jų gyvenamoji vieta, nei gydymo ịstaiga.

Duomenų rinkimas. Interviu buvo ịrašomas ị diktofoną. Išjungus diktofoną, kai kuri informacija buvo užrašoma, o vèliau panaudojama formuluoti tyrimo išvadas.

Tyrimo dalyviai:

Interviu Nr. 1. Tyrimo dalyviai A.J. (40 m.) ir V.K. (42 m.) prieš 4 metus neteko dukros G.K. (16 m.). G.K. buvo bendras A.J. ir V.K. vaikas. Gydymosi laikotarpis nuo diagnozès patvirtinimo dienos -3 metai. Šeima augina sūnų $(16 \mathrm{~m}$.) iš pirmos vyro santuokos. Tarp vaikų buvo artimas ryšys, tačiau ligos metu santykiai nutrūko.

Interviu Nr. 2. Tyrimo dalyvė I.L. (43 m.). Prieš 1,6 m. neteko dukros E.L. (12 m.). Gydymosi laikas nuo diagnozès patvirtinimo dienos 9 mèn. Tyrimo dalyvè turi dar vieną 21 metų dukrą, kuri gyvena atskirai ir nesutiko dalyvauti tyrime. Tyrimo dalyvė gyvena su tèvais, E.L. seneliais. Su vyru, E.L. tẻvu, tyrimo dalyvė išsiskyre iki E.L. ligos diagnozavimo.

Interviu Nr. 3. Tyrimo dalyvè S.V. (41 m.). Sūnaus E.M. (18 m.) neteko prieš 4 metus. Gydymosi laikotarpis nuo diagnozès patvirtinimo dienos 2,5 metų. Tyrimo dalyvè gyvena su vyru, kuris nèra E.M. tèvas, tačiau augino berniuką nuo 6 mènesių.

Interviu Nr. 4. Tyrimo dalyvė G.G. (36 m.). Sūnaus L.P. (2,3 m.) neteko prieš $1,7 \mathrm{~m}$. Gyvena su mama ir $12 \mathrm{~m}$. dukra. Išsiskyrusi. Tèvas ligoninejje sūnų lankè.

Pateikti duomenys rodo, kad tyrimo dalyvių vaikų gydymosi sveikatos priežiūros ịstaigose laikas buvo nuo 10 mèn. iki 3 metų. Amžius nuo 2,3 metų iki 18 metų. Tèvų amžius nuo 36 iki 43 metų, t.y. darbingo ir socialiai aktyvaus žmogaus metai.

\section{Tyrimo rezultatai}

Šeimos reakcija ị žinią apie vaiko onkologinę ligą. Žinia apie sunkią vaiko ligą tėvus pasiekia netikètai ir nelauktai $[2,14,16,20,21]$. Pirminè tèvų reakcija visais atvejais skirtinga, tačiau kartu ir labai panaši.

Informantė I.L. pasakoja: „< ..> Nežinau. Iš proto vos neišsikrausčiau <...>“. [ I.L., pusiau struktūruotas interviu, 2018 m. kovo mén.].

Informantė S.V. dalinasi: „, ,..> Vat, gydytojas sakau, man buvo, kad E.M. buvo paguldytas ligoninèj. Vat, kaip neurologè ten nusiuntė ir man ị darbą paskambino, kad, sako, reikia mums pasimatyti. Suprantat, aš greitai tenai ị autobusą, nulekiu ir, kad žinotumèt, man kai pasakè kabinete, kad yra tie augliukai, aš sakau, vat man kaip, nu, nemoku pasakyt, ir žemė slydo, ir viskas, ir viskas. Kaip aš parẻjau namo, aš to neatsimenu. Aš tik parejjus namo pasakiau vyrui, kad E.M. galvoj rasti augliukai. O kad jie piktybiniai ar kokie, man nedaejjo, buvo tas tik, kad vat, rasti. Galvoj yra, žinot, galvoj rasti, jetau jetau <...>“. [S.V., pusiau struktūruotas interviu, 2018 m. kovo mèn.].

Apie tai pasakojo ir informantė A.J. „, $<$..> Aš sureagavau $\mathfrak{i}$ tai visiškai viena, nes vyras buvo išejęs, kadangi mes ten per savus bandėme papulti, kad greičiau mums padarytų tyrimus, tai vyras buvo nusprendęs nueiti, tai sakau nueik, nupirk Rafaello děžutę, nu daktarei, sakau, vis tiek jau čia tyrimai baigèsi, nu, čia vietoj gi parduotuvytè, nes, nu, sakau gi, gražu būtų, čia toks gestas. Jis tik išejo ir mane visi gydytojai pasikviete, ir man vienai pasake. Bet mums pasakè netvirtai. Mums pasakè arba vandenys, arba......vidinis sinusitas, arba auglys galvoje. Mums nepasakè iš karto, vat kaip vat, paukšt ir kažkokia žinia. Paskui vyras už mane protingesnis juk. Paskaite visas šitas diagnozes ir jis iš karto 
suprato, o aš ne. Aš dar kažkaip... bet pirma mintis buvo, kad mano vaikui nebeskaudètų... daugiau nieko nenorejjau, nes jai ištisai skaudèjo galvą ir, kaip suprantu, skaudejo LABAI“ (emocionaliai ištartas žodis). [ A.J pusiau struktūruotas interviu, $2019 \mathrm{~m}$. vasario mèn.].

Psichosocialinės pagalbos svarba gydymosi laikotarpiu. Daugelis autoriu $[22,3,8]$ atkreipia dèmesị ị komandinio, kompleksinio darbo svarbą, siekiant palengvinti ir vaikų, ir tėvų prisitaikymą prie artèjančios netekties momento. Atliktos studijos [1,5] parode, kad neužtenka galvoti tik apie vaiką. Būtina kompleksinè pagalba visai šeimai.

Informantè A.J. dalinasi savo prisiminimais apie pažinti su socialiniu darbuotoju, kurio pagalba jai buvo ypač vertinga gydymo įstaigoje. „<...> Pasirodè tada, kai prasidejo dokumentų tvarkymai, visi būtent... Oi, tai buvo didelis džiaugsmas, daug kur, labai daug padejo. Čia didelis pliusas. Pasirodo, prie šitos diagnozès man priklausè atskira palata (nurodyta ankstesnè gydymo ịstaiga), man priklause biuletenis, kad aš neturejjau iš tikrujų dešimt dienų blaškytis kairèn dešinèn, ieškot kur pamiegot, kad būt šalia< _.. >“. [ A.J. pusiau struktūruotas interviu, $2019 \mathrm{~m}$. kovo mèn.].

Socialinio darbuotojo kompetencija [7, 12], informavimas ir konsultavimas tinkamu laiku, yra svarbūs akcentai, kurie gali padèti šeimai ịveikti kilusius finansinius ir socialinius sunkumus. Informante S.V. prisimena: „<..> buvo, man jau pasibaige šimtas dvidešimt dienų, ir dar daugiau, ir papildomų pasibaigè. Gavosi, kad man ir darbas nebegali tęsti nemokamų. Socialinis darbuotojas atèjo ir davė minti, sako S.V., o jūs pabandykit ị Vilnių, pagrindiniam ten Sodros direktoriui parašyti laišką, kad išimties tvarka. Parašiau ir dar gavau pinigèlių. Vat, labai padejo< <..." . [ S.V. pusiau struktūruotas interviu, $2019 \mathrm{~m}$. kovo mèn.].

Socialinių garantijų, darbo išsaugojimo klausimai ryškèja, mažèjant laikinojo nedarbingumo trukmei. Keičiasi santykiai su darbdaviu, dideja socialinè atskirtis, mažejja savivertés jausmas. Informantė I.L. pasakojo, jog „, <..> po tu priklausomų dienų pradèjo krapštyt. Liepẻ grịžt ị darbą. Aš pradejjau tos auklès ieškot ir... ...nu, paskui jau viskas <... .“. [I.L. pusiau struktūruotas interviu, 2019 m. kovo mèn.]. Toliau I.L. pasakojo, kad , , ..> baisu (verkia). Bendradarbės visos, tai jo, jos suprato, bet vadovè... iš pradžių atrode, kad viskas gerai, kad žmogiška ir tą psichologą padèjo surast, ir aš kas dvi savaites važiuodavau į Vilnių, tuo pačiu ir su vyresnèle dukra pabūt galèjau, o po kokių kelių mėnesių... rèžè, kaip iš dangaus perkūnas. Nežinau kas ten buvo, ar ten buvo sugalvota, kažkur, kažkas, kažką kalbejjo, nu aš nežinau kaip ten viskas buvo, bet aš patapau pati blogiausiai dirbanti, pastoviai manęs nebūna, nu apeliavo ị tai, kad kas antrą penktadienį manęs nẻra, viskas blogai patapo. $\mathrm{Nu}$, tai vat ir išejau iš darbo, nors taip nebuvo. Buvo didelis smūgis, biškị sveikata sutriko“. [I.L. pusiau struktūruotas interviu, 2019 m. kovo mèn.].

Informantė G.G. labai aiškiai įvardijo psichologinès paramos būtinumą. ,, $<$..> Gal labiausiai to, kad su kažkuo pasikalbet iš tikrujų. Nu buvo (darbuotojo vardas)...nu, sakau, išklauso, viską, nu, bet trūksta to tokio. Norisi vis tiek tos tokios gal nu gal ne kaip paguodos, bet nu to tokio žodžio, kažkokio tokio palaikymo, kad tu nebe nebe nenuleistum rankų, kad vis tiek kovok, nu vat tokių.... Trūksta. Reikètų ir mamom tenai psichologo, su kuriuo galètų iš tikrujų pabendrauti.... to tikrai labai reikia. Nežinau, man to tikrai labai reikèjo labai“. [G.G. pusiau struktūruotas interviu, 2019 m. kovo mèn.].

Informantė I.L. pasakoja: „, ,..> Neigalumą mums tik kai baiginėjosi tas nu radioterapija, kad namuose kažką būtų lengviau, kad ten ir ị tas tarnybas eiti, vežimèli gauti...sunkus atvejis ten ką nors gauti. Priklauso ten, kaip paskiria tą DNT, ar reikia visiškos pagalbos, ar tau ten tik šiaip. Jei šiaip, tai nelabai ir gausi. Mes staliuko prie lovos maistui negavom, nepriklauso. Socialinè (nurodytas vardas) nusiuntė tuos dokumentus. Mus tikrino.<... >“. [I.L. pusiau struktūruotas interviu, 2019 m. kovo mèn.]. Informantė atskleidè ịvykị, kai dukters sveikatai sparčiai blogejjant, tikrinimo metu jai teko žengti kelis žingsnius kambaryje: , , ...> E.L. atsistojo, kažkiek paejjo ir to užteko. Dieve. Liko sunkus neigalumas, bet ta, kaip ten, globa, kad aš galiu ja rūpintis, man kažkokia išmoka priklauso, kad galiu eiti prašyti didesnių tų priemonių palengvinti. Ne, tokios aš negavau <... >“. [ I.L. pusiau struktūruotas interviu, 2019 m. kovo mèn.].

Psichosocialinės pagalbos poreikis šeimai. Tèvams netekus vaiko, o seneliams - vaikaičio, reakcijos i netektị visų skirtingos ir išgyvenamos savaip. Draugai tolsta, nes nežino kaip bendrauti, kaip elgtis. Socialinè atskirtis formuojasi savaime ir gilina gedulo laikotarpio išgyvenimus. Nors artimujų parama ir palaikymas labai svarbus kiekvienos šeimos gyvenime, tačiau atliktas tyrimas [10] parodè, kad giminaičiai ne tik nepadeda, bet ir turi neigiamos itakos sielvarto, gedejimo metu.

Gydytojo, psichologo, socialinio darbuotojo laiku teikiama kompleksinè pagalba padètu šeimoms apsiprasti su artẻjančia netektimi, parengtų būsimam gedèjimo laikotarpiui [14]. Prisiminimai, ryšys su vaiku, ypač svarbūs gedintiems tèvams, apsiprantant su netektimi. Tai patvirtina ir atliktas tyrimas [4], kuris parodè, jog tèvams labai svarbu išlaikyti emocinį ryšį su vaiku, kuris ,išèjo“.

Informantė A.J. prisimena: „< ..> Nu, tada, kai gulejome, tai kaip viena didele šeima buvo tas skyrius $<$... >“. [A.J. pusiau struktūruotas interviu, $2019 \mathrm{~m}$. vasario mèn.].

Informante G.G. papasakojo apie skyriuje patirtą bendrumo jausmą: „< ..> Bendrauti skyriui su mamom tas labai 
padeda iš tikrujų nes vienas kito palaikymas, toks bendras kumštis, nu ką aš žinau, bet reikètų ten to žmogaus, kuris, nu tikrai.... Bet čia kaip kiekvienas žmogus, kaip kas ištveria, nemoku net nupasakot to jausmo iš tikrujų < ..>". [G.G. pusiau struktūruotas interviu, $2019 \mathrm{~m}$. kovo mèn.].

Bendrystès svarba atsispindi ir informantès S.V. pasakojime: , $<\ldots>$ O kaip mums asmeniškai, nugis ne paslaptis, pradèjom bendrauti viena mama, antra, trečia mama, nu tai pakaitom leki ten už kampo pasibūt. Pasibūni, išsiverki, kad vaikai nematytų. Parkeliai, kaip sakau, ten ašarom aplaistyti mūsų, net upè turèjo pasikelt, taip niekas, niekas su mumis. Kaip aš sakau mamai, sužinojus diagnozę, kad vaikas serga vėžiu, aš net nežinau, gal paprasčiausiai žmogiško, tėviško, motiniško paaiškinimo $<$... > . [S.V. pusiau struktūruotas interviu, $2019 \mathrm{~m}$. kovo mèn.].

Situacija iš esmès pasikeičia po vaiko netekties, kai šeimos sielvarto krizės etape turi pasirūpinti laidotuvėmis. Visi informatai yra iš skirtinų Lietuvos regionų.

Informatė A.J. pasakoja: „< ..> Kai G.K. išvežè, džiaugèmès, kad nebuvo koridoriuje vaikų. Nieko nebuvo. Mes nuvažiavom iki morgo, mes ten atsistojom. Pasake mums, kad ta prasme yra penktadienis, iš morgo pasiimt galit, kadangi tokia liga, ir šiandien, jeigu spėsit iki trečios valandos. Vienuolika kai „,išejo“, dvylika, kai išvežè, nes gi dar valandą palatoje. Šiaip tai su vyru abudu... Mums buvo toks palengvèjimas. Kiti, gal būt, nuo galvos plaukus rautųsi, o mes šypsojomės, kad jai jau gerai. Atsisėdom parkely šitam (gydymo įstaigos), morgas žinot kur ten? Sakau, žinai ką, skambinam (miesto, kuriame gyvena tyrimo dalyvis, ritualinių paslaugų tarnybos pavadinimas). $\mathrm{Nu}$, paskambinom. Vyras sako, žinai, mūsų dukrą reikia pasiimti. Iki trijų spėsi?.. $\mathrm{O}$ tai ką jūs planuojat daryt? Kremavimas. Gerai. Supratau. Reikia dèl kremavimo tartis, hhhhm. Tai dar palaukit, tai dar ne viskas. Mirties liudijimo reikia. Tai reikia ị (nurodytas miestas) važiuot, mirties liudijimą išsiimt. Gerai, sakau, skambinu (socialinio darbuotojo vardas). Sakau (socialinio darbuotojo vardas), padèsi? Ta sako, gerai, skambinu į meriją, sutvarkysime visą šitą dalyką. Gerai. Po dešimt minučių paskambino (miesto, kuriame gyvena tyrimo dalyvis, ritualinių paslaugų tarnybos vadovas), gerai, mašiną išsiunčiame, kremavimas rytoj dešimtą Kèdainiuose < ... >“. [A.J. pusiau struktūruotas interviu, $2019 \mathrm{~m}$. vasario mèn.].

Informantė G.G. dalinasi savo įžvalgomis apie pagalbos svarbą po vaiko netekties: „, $<$..> Vat, tos socialinès, bet aš tai žinojau iš tikrujų, bet yra žmonių, kurie nieko nežino, bet net nežinau, tuo momentu būčiau pasimetus, nes mat būtu to visko per daug, tai tikrai būtų reikalinga pagalba, bet yra žmonių, kuriems labai reikalinga. Vien tas pasidomejjimas, vien tas, manyčiau, padeda, kad tu dar kažkam esi reikalingas, vat, vien ta mintis, kad tavęs kažkas klausia....o gal tau reik pagalbos, ar kažkas vat... Čia yra labai sunku <..."“. [G.G. pusiau struktūruotas interviu, 2019 m. kovo mèn.].

Dėmesio aktualumą pabrèžia ir informantè I.L., ịvardijusi, ko jai labiausiai trūko: „< ..> Psichologo labiausiai ar bent kažko, kas paklaustų <..."“.[I.L. pusiau struktūruotas interviu, $2019 \mathrm{~m}$. kovo mèn.].

Tyrimo metu aiškèjo, kaip svarbu šeimoms, praradusioms vaikus dèl onkologinès ligos, gauti socialinio darbuotojo paslaugas ne tik gedejimo laikotarpiu [9], bet ir ilgiau. Teirautasi, kokia artimujų, draugų itaka, (ne)pagalba, patyrusiems vaiko netektị.

Informantė S.V. sako: „, ,..> Pasiskambint, pašnekèt, gal ị kokị filmą. Draugè irgi sako, einam ị koncertą. Nu, nenoriu. Matot, draugè yra draugè, atsiprašant draugę tu gali pasiųst, o čia vis tiek yra, nu, bent iš mano pusès, jaučiu pagarbą, sakysim, svetimam žmogui. Tu gali mandagiai atsisakyt, bet toks žmogus turètų mokèt sudomint. Jis, toksai žmogus, turètų mokèt.....aš galų gale, vat, būna toks variantas, sakysim, nu toks elementarus, toks primityvus, galų gale pavasarị žibučių i mišką paskint, suprantat, grynu oru pakvẻpuot, o kodèl ne...., nes tu sèdi namuose, tu nieko neveiki, tu sédi, tu rašai, tu skaitai < ... >“. [S.V. pusiau struktūruotas interviu, 2019 m. kovo mèn.].

Einant šios ligos keliu, matant blogèjančią vaiko sveikatą, išgyvenant netektį, pirmiausia galvojama apie artimiausius žmones, draugus, ị kuriuos būtų galima atsiremti. Informantų patirtys atskleidžia šios situacijos trapumą ir individualumą.

Informantė G.G.: , „<..> reikètų žmogaus, kuris tą supranta, nes eiliniai draugai, nu, ką jie gali, nu, jie to nepatyrę. Jie tik gilina, tikrai, tą žaizdą...kaip tas buvo, kaip anas buvo ir tie klausimai visokie ir tu automatiškai galvoji, mąstai apie tai. Aišku, pas mane buvo mama, tai viskas paprasčiau buvo. Mes jau viską žinojom, kaip ką daryt. Aišku, jeigu ne mama, aš nežinau, ar aš pati viena būčiau susitvarkius, nes aš tikrai buvau nežinia kur. Galvoj kas darèsi, taiiiiii, nes buvo tikrai be galo sunku. Čia, manau, kiekvienam toks dalykas, juk yra sunku laidoti savo vaikąa“. [G.G. pusiau struktūruotas interviu, $2019 \mathrm{~m}$. kovo mèn.]. Išjungus diktofoną, informantė G.G. pasidalino savo emocijomis apie draugų bendravimą: „<...> nu, kas iš to. Parašo žinutę ir čia pat rašo, neva, bijau Tau rašyti, nes nežinau kaip kalbèti...<... .". [G.G. pusiau struktūruotas interviu, 2019 m. kovo mèn.].

Informante A.J. pasakoja: „, $<$..> Giminaičiai, nors jų nei vieno neliko. Nei mano mamos, nei mano sesers, nieko. Mūsų gyvenime, po šiai dienai, mes nebendraujame. Su mama labai jau to ryšio ir nebuvo, o su sese dar buvo ryšys, bet sesuo, dabar galvoju... jo, dar buvo mūsų ta pradinė stadija pusantro mènesio, tas gydymas ir ji norejo pas mane ateit, žinai, ir sakau, ar jūs nesloguojat, nesergat, sakau, nu, nes pas mus karantinas tuomet buvo ir negali sergantis ateit. 
Ir, vienu žodžiu, ji pas mane nepasirode < ... >“. [A.J. pusiau struktūruotas interviu, $2019 \mathrm{~m}$. vasario mèn.].

Pagalba iš šalies, rūpestis, dėmesys, tai labai svarbūs akcentai, kurie padeda jausti paramą, šilumą ir demesị. Formalus, šaltas, abejingas bendravimas dažnai žeidžia ir skaudina. Informante S.V. pasakoja: „, _..> Čia toj sistemoj, kur tą darbą ruošiat, tokia spraga tokia didžiulè, tokia spraga. Aš nesigilinsiu i politiką, bet kaip aš sakau padèt žmogui, kaip tu, kaip sakau, kai žinai, kad vaikas pasveiko, plojam visi, o kai žinai, kad vaikas mirè, verkia visi vieną dieną. Likusị gyvenimą verkia tẻvai. Niekas, niekas i mus nežiūri. Kai nuejjau ị socialinị tvarkytis dokumentų, tik ačiū, ačiū, užuojauta. Kad paklaustų, gal reikia psichologo ar dar kažko... niekas nieko <..."“. [S.V. pusiau struktūruotas interviu, 2019 m. kovo mèn.].

Tikejimo galia palaiko, stiprina ir neleidžia pasiduoti. Informantė G.G. dalinasi: „, $<$..> Aš turbūt išmokau apie nieką negalvoti, gyventi čia ir dabar, ir džiaugiausi, kad L.G. vat ejo per tą visą skyrių, jis buvo toks linksmas, energingas. Man tas padejjo, man pačiai net buvo kaip šiokia tokia pagalba, kad mano vaikas toks, bet tos minties, kad jis gali išeiti, pas mane nebuvo. Aš visą tą gydymą tikèjau, kad jis pasveiks. Ta viltis mano turbūt buvo neužmušama $<$... >“. [G.G. pusiau struktūruotas interviu, $2019 \mathrm{~m}$. kovo mèn.].

Informantė I.L. pasakoja: , ,_..> Aš taip kažkaip, nu nežinau, ką aš žinau, galvojau, kad noriu pas vaiką (verkia). Ji kaip pasakè, kad tas sapnas taip reiškia. Kai iš darbo atleido, aš ir tada duris sapnavau, bet aš jas laikiau, bet jos vèrési visa jèga. Aš, kai dukra jau sirgo, ligoninèj gulèjo, pasakè, kad nieko, kad čia yra tiesiog ,išejimas“, man, atsimenu iš fondo (nurodytas pavadinimas) viena savanore tuos pampersus atnešè, žinau vardą, pavardę, bet gal nesakysiu čia, tai patare paskaityti vieną knygą. Aš ją perskaičiau. Nupirko dukra vyresnioji, atnešè ị ligoninę, tai aš ją perskaičiau, turiu kažkur namuose ir ta knyga labai man padejo neišeiti iš proto. Knyga Silvijos Braun „Gyvenimas anapus“. Ir aš ją va perskaičiau... padejo. Lengviau paleidau (verkia), tiesiog ją paleidau, jai ten geriau. Sakau, ateik pas sesę, ateik, papasakok, nes aš neprisiminsiu visko. Tą pačią dieną, kai „išèjo“, ateidavo pas sesę i sapnus. Sapnavo taip, kad ji sveika ir graži. Ir taip sapnavosi, kaip toj knygoj parašyta, o dukra tai neskaite tos knygos ir aš jai po to papasakojau < ... “". [I.L. pusiau struktūruotas interviu, 2019 m. kovo mèn.].

Apie ryšį su vaiku ir tikèjimo svarbą informantẻ A.J. sako: „<...> Turbūt stipri esu. Tai traukiau visas kitas, su kuriomis draugavome. Viena norejo galą pasidaryti, tai pasakiau, kad jei išeisi, tai su vaiku danguje nebūsi, tu būsi visiškai kitur. Kita norejjo tik pasikalbèt. Tikejjimas. Man gali skambinti bet kas. Aš žinau, kad G.K. nori, kad paděčiau. Aš net kai kuriems kunigams, kaip suprantu, esu per daug aštri. Ginčijuosi aš su jais. Man pačiai reikia stiprybės padèti kitiems, jei priima mano pagalbą. Aš turiu ir žinau, kad G.K. šalia. Čia yra tikejjimas, kaip aš sakau, matyti ženklus, pasitikejjimas kas vyksta viršuje, kiekvienas rytas yra dovana, atsikèlei ir, ačiū Dievui, eik pirmyn, nes nežinai, kas rytoj bus <... >“. [A.J. pusiau struktūruotas interviu, 2019 vasario mèn.]. Informantè sako, $\mathrm{kad},,<\ldots>$ Praejo jau 3 metai ir tas tikejimas mano labai stiprus. Netgi vat kalbant apie vyro tèti, tie žodžiai Amžinaji Atilsį sakome, o dukrai nesame dar pasakę (Pauzè...). Ir mes žinome, vat, sèdžiu, liūdna. Kiti važiuoja ant kapų, sakau nevažiuosiu, sakau aš nenoriu ten. Ten jos nèra. Jei aš noriu šnekètis, šnekèsiu čia“. [A.J. pusiau struktūruotas interviu, $2019 \mathrm{~m}$. vasario mèn.].

Savitarpio pagalbos poreikis, siekiant greičiau prisitaikyti prie vaiko netekties. Kompleksinè profesionali socialinio darbuotojo pagalba [11] netekties išgyvenimo laikotarpiu būtina todèl, kad visas išgyvenimo ciklas būtų suprastas kaip kintama būsena.

Informantè G.G. atkreipia dèmesị ị detalę, kuri būtų svarbi organizuojant savitarpio pagalbos grupes: , $<\ldots>$ Taip sakykim, jei rinktųsi tos mamos, kurios ten buvom kaip kumštis, tai aš tikrai noreečiau, važiuočiau, bet jei svetimi, gal nebenoreečiau vèl klausytis ir girdèti tų pačių... man tai aštrintų mano situaciją. Aš nenoréčiau vèl ị tai grimzti iš tikrujjų...nu, jūs mane supratot. Dar vieta...nu, kaip tas, nu, Krizių centras, tai mane, vat, gąsdina. Vat, kai yra tų žmonių, kur geria alkoholi...irgi tas pavadinimas. Geriau sugalvotas kažkaip kitaip... <...>“ [G.G. pusiau struktūruotas interviu, 2019 m. kovo mèn.].

Informantė I.L. pastebi: ,<..> Tokioje grupeje būtų gerai, bet tokioje grupeje vis tiek turi būti psichologas ar tas socialinis, kad mokètų suvaldyti, nes mes ten vienos pačios būdamos ten nubliausim. Na ir kas iš to? Turi išklausyti, kažką pasakyti tikrai, kad paskui dèliot tas mintis (verkia). Man blogai. Kitos negali valgyti, o aš atvirkščiai, nervus valgau ir svorio priaugau (verkia). Psichologè sakè, kad tai normalu, bet reikia ieškoti kažką kitą. Eit vaikščiot ar dar kažką veikt. Va, su šuniu pradejjau daugiau bendraut < ... >“. [I.L. pusiau struktūruotas interviu, 2019 m. kovo mèn.]. Apie bandymus burtis, išsikalbèti, ,išsiventiliuoti“ toliau pasakoja informante I.L.: , , ..> Čia viena mama Kaune organizavo... ne iš tos grupès, jos vaikelis pasveiko, bet ji organizavo, tik nežinau ar toliau vyksta? Išsikalbèt reikia (verkia) < ..> “.[I.L. pusiau struktūruotas interviu, 2019 m. kovo mèn.].

Galvojant ir planuojant organizuoti savitarpio pagalbos grupes, svarbu gerai suprasti šių šeimų bendrumą, emocijas. Klausantis informantų, neapleido mintis, kad tai onkologinès ligos keliamų problemų suvienyti žmonès ir suprasti juos galètų tik tą patị kelią nuejję tẻvai, mamos, broliai, seserys, patyrę tas pačias problemas. 
Informantė A.J. kategoriška: „< ,.>> Aš prisileisčiau. Tik aš kitoks žmogus, ir jei mane pradètų stabdyti, kad aš nusišneku, aš... tiesiog ten nebeičiau, nes, nu, pavyzdžiui, pas mane buvo ta situacija, kad praeję buvo, dabar galvoju... pora mènesių po G.K ,išèjimo" aš nuejjau ị bažnyčią ir nuejau pas kunigą po Mišių ir sakau, man reikia ligonių patepimo. Tas žiūri ị mane ir klausia, ar aš sergu. Sakau ne, mano siela serga. Už durų buvo mūsų kitas kunigas. Tas pradèjo juoktis ir sako, kad su manim pasiginčytų, bet sako gerai, o tas buvo naujas kunigas, taip ir liko nieko nesupratęs. Aš ieškojau pagalbos, o ị tokią grupę būčiau ejjusi padèti kitoms mamoms, nes aš suvokiau, kad aš žudytis neisiu, jei norèsiu atsipalaiduoti, tai ne tos tabletès, o pasirinksiu stikliuką degtinès. Aš jị išgersiu dèl to, kad man mintys nurimtų, bet ne dèl to, kad aš norèčiau prisigert, paskandint savo visą skausmą, vat, tai aš suvokiu ir, pavyzdžiui, vyras man sako, paminklą pastatys, kad aš ištraukiau iš to liūno, kur visi būtų nuejję kažkur tai <... >“. [A.J. pusiau struktūruotas interviu, 2019 m. vasario mèn.]. I t pokalbị įsitraukẻ A.J. vyras, kuris visą laiką, kol mes kalbejjomès su A.J., bendravo su broliu pranciškonu. Nugirdęs A.J. komentarą, V.K. pastebèjo, „, $<>>$ jog naudinga būtų organizuoti savitarpio pagalbos grupes atskirai motinoms ir atskirai vyrams, kadangi ị tokią grupę ateitų ir tie vyrai, kurie vaiko ligos pradžioje paliko šeimas $<$... $>$ ". [V.K. pusiau struktūruotas interviu, $2019 \mathrm{~m}$. vasario mèn.].

\section{Išvados}

1. Lietuvoje stebimas vaikų onkologinių ligų sergamumo rodiklių didejimas. Higienos instituto pateikti statistiniai duomenys rodo, kad profilaktikos programų vykdymas, visuomenès švietimas, laiku atlikta diagnostika ir pradètas gydymas leidžia išsaugoti vis daugiau vaikų gyvybių.

2. Vaiko onkologinè liga iš pagrindų keičia šeimos gyvenimą: atsiranda socialine atskirtis, persiskirsto pareigos ir atsakomybė, patiriami dažnai nepakeliami finansiniai sunkumai. Socialinio darbuotojo profesionali psichosocialinè pagalba, aprépianti šeimos konsultavimą, informavimą, tarpininkavimą ir atstovavimą, ankstyvoji kompleksinè pagalba bei jos tęstinumas šeimai po vaiko netekties, yra labai svarbi.

3. Atliktas tyrimas patvirtino socialinio darbuotojo psichosocialinės pagalbos reikalingumą visai šeimai, praradusiai vaiką dèl onkologinès ligos. Visi informantai pažymėjo, kad socialinis darbuotojas galètų padèti užmegzti glaudesnius ryšius su gydytojais, kuomet reikalingas aiškus ligos apibūdinimas, detalūs atsakymai ị tėvų klausimus. Tyrime išryškèjo, kad visos šeimos, praradusios vaikus dèl onkologinès ligos, išgyvena krizę, pasigenda specialistų, draugų ar giminių demesio. Visi informantai teigè, kad profesionali ankstyvoji psichosocialinè pagalba, teikiama socialinio darbuotojo, palengvintų tèvų išgyvenimus ir prisitaikymą vaiko onkolo- ginès ligos laikotarpiu, o kompleksinès pagalbos tęstinumas sušvelnintų gedejjimo laikotarpị ir padètų greičiau suvokti tikrovę. Šeimos dalyvautų savitarpio pagalbos grupèse, kurias organizuotų ir joms vadovautų socialiniai darbuotojai.

\section{Literatūra}

1. Aho AL, Tarkka MT, Astedt-Kurki P, Sorvari L, Kaunonen M. Evaluating a bereavement follow-up intervention for grieving fathers and their experiences of support after the death of a child-a pilot study. J Death Studies 2011;35(10):879-904. https://doi.org/10.1080/07481187.2011.553318

2. Boman KK, Kjällander Y, Eksborg S, Becker J. Impact of prior traumatic life events on parental early stage reactions following a child's cancer. J PLoS ONE 2013;8(3), e57556.

https://doi.org/10.1371/journal.pone.0057556

3. Brown E, Warr B. Supporting the child and the family in paediatric palliative care. London, UK: Jessica Kingsley Publishers 2007. http://search.ebscohost.com.db.kaunokolegija.lt/login.as px?direct $=$ true $\& \mathrm{db}=\mathrm{e} 000 \mathrm{xww} \& \mathrm{AN}=202365 \&$ site $=$ ehost-live

4. Cacciatore J, Flint M. Mediating grief: postmortem ritualization after child death. J Loss \& Trauma 2012;17(2):158-172.

https://doi.org/10.1080/15325024.2011.595299

5. Cimete G, Kuguoglu S. Grief responses of turkish families after the death of their children from cancer. J Loss \& Trauma 2006;11(1),31-51.

https://doi.org/10.1080/15325020500194455

6. Gaižauskaitė I., Valavičienė N. Socialinių tyrimų metodai: kokybinis interviu: vadovèlis. Vilnius: Registrų centras, 2016:384.

7. Johnson L.C. Socialinio darbo praktika. Bendrasis požiūris. Vilnius. VU specialiosios psichologijos laboratorija, 2001:372.

8. Kearney JA, Salley CG, Muriel AC. Standards of psychosocial care for parents of children with cancer. Ped Blood \& Cancer 2015; 62(5):632-683.

https://doi.org/10.1002/pbc.25761

9. Kübler-Ross E. Apie mirtị ir mirimą. Vilnius, 2008:336.

10. Laakso H, Paunonen-Ilmonen M. Mothers' experience of social support following the death of a child. J Clin Nurs 2002;11(2):176-185.

https://doi.org/10.1046/j.1365-2702.2002.00611.x

11. Leliūgienė I. Žmogus ir socialinè aplinka. Kaunas: Technologija, 1997:96.

12. Lietuvos Respublikos Seimas. Socialinių paslaugų įstatymas Nr. X-493, 2006. https://www.e-tar.lt/portal/lt/legalAct/ TAR.91609F53E29E

13. Lietuvos Respublikos sveikatos apsaugos ministerijos Higienos instituto Sveikatos informacijos centras. Naujai susirgusių asmenų skaičius pagal metus. https://stat.hi.lt/default. aspx?report_id=136

14. Loscalzo MJ. Handbook of oncology social work: psychosocial care for people with cancer. Edited by Christ G, Messner C, Behar L. J Psycho-Oncology 2016;25(3): 359-360. 
https://doi.org/10.1002/pon.4101

15. Onkologinès ligos. Nacionalinis vèžio institutas. https://www.nvi.lt/onkologines-ligos/

16. Polukordienė O. K. Netekčių psichologija. Vilnius, 2008:112.

17. Šeškevičius A. Paliatyvioji slauga. Kaunas. KMU, 2008:250.

18. Tamošauskienė J., Aleknavičienė B., Jakubavičiūtė D. Onkologinių ligų profilaktika: metodinè-informacinè medžiaga visuomenès sveikatos specialistui. Vilniaus m. savivaldybès visuomenės sveikatos biuras, 2013. https://www.nvi.lt/uploads/ pdf/leidiniai\%20pacientams/Profilaktika.pdf

19. Tidikis R. Socialinių mokslų tyrimų metodologija. Vilnius. LTU, 2003:628.

20. Wong MYF, Chan SWC. The qualitative experience of Chinese parents with children diagnosed of cancer. J Clin Nurs 2006;15(6):710-717.

https://doi.org/10.1111/j.1365-2702.2006.01297.x

21. Noncomunicable diseases. Data ant statistics.WHO. http:// www.euro.who.int/en/health-topics/noncommunicable-diseases/cancer/data-and-statistics

22. Žemaitienė N., Bulotaitė L., Jusienė R., Veryga A. Sveikatos psichologija: vadovèlis. Vilnius. Tyto alba, 2011:424.

23. Žydžiūnaitė V., Sabaliauskas S. Kokybiniai tyrimai. Principai ir metodai. Vilnius. Vaga, 2017:376.

THE NEED FOR A SOCIAL WORKER'S

PSYCHOSOCIAL SUPPORT FOR A FAMILY WHO

HAS LOST A CHILD BECAUSE OF

AN ONCOLOGICAL DISEASE

V.Kondratavičienė, I.Šikšniuvienė

Keywords: oncological disease, social work, social worker, family, the need for psychosocial support.
Summary

Death of a child leaves an extremely deep and painful wound in the heart of the parents. There is an increase in the incidence of oncological diseases in Lithuania. It is not easy to reconcile, accept the fact, not be angry at life and destiny, and try to get back to everyday life. In order to help parents to survive the loss they require support that responds to their hopes and needs and would help them not to feel socially excluded, would show that the help is available and can be obtained. Therefore, it is necessary to find out what psychosocial help would be the most helpful for parents who have lost their child due to oncological disease. The study revealed that acceptance and reconciliation with the current situation depends particularly on the initial contact with the treating physician. His attention, clear description of the illness, discussion of the treatment, constant bilateral communication facilitates the stage of reconciliation with the disease. The need and importance of timely complex (including physician, psychologist, social worker) assistance throughout the treatment period and especially after the child's loss was noted. The study also revealed the need for interinstitutional cooperation to help the family survive the loss, provide the necessary psychosocial assistance, monitor, analyze changes throughout the mourning and in many cases even longer. Correspondence to: virginija.kondrataviciene@go.kauko.lt

Gauta 2019-10-30 